\title{
Monitoring Dynamics of Urbanization in Yenagoa, Nigeria Using Landsat Series
}

\author{
Lamidi R.B. ${ }^{1}$, Agbiyaowe C.D. ${ }^{2}$, Fakeye A.M ${ }^{1}$ and Okonufua E. ${ }^{1}$ \\ ${ }^{1}$ Nigerian Building and Road Research Institute (NBRRI) \\ ${ }^{2}$ African Regional Institute for Geospatial Information Science and Technology (AFRIGIST)
}

Nigeria

\begin{abstract}
The expansion in the human populace has brought about expanding paces of ecological changes in the recent decade. This expansion is liable for this change in urban development.The study aimed to assess the urbanization dynamics in Yenagoa between 1989-2016 using remote sensing and GIS techniques in data acquisition, analysis, and presentations. The results showed that in the periods 1989, 2002, and 2016, the built-up area showed a consistent increase over time, from $11.69 \mathrm{~km}^{2}(9.6 \%)$ in 1989 to $29.851 \mathrm{~km}^{2}(24.5 \%)$ in 2002, and $76.33 \mathrm{~km}^{2}(62.6 \%)$ in 2016 of the total area. The bare land covered about $1.25 \mathrm{~km}^{2}(1.02 \%)$ in 1989 but decreased to about $0.02 \mathrm{~km}^{2}(0.02 \%)$ in 2002 and increased again to $0.97 \mathrm{~km}^{2}(0.8 \%)$ in 2016. Similarly, the area covered by water body increased from $2.46 \mathrm{~km}^{2}(2.02 \%)$ in 1989 down to $2.48 \mathrm{~km}^{2}(2.03 \%)$ in 2002 and increased slightly to2.50 $\mathrm{km}^{2}(2.05 \%)$ in 2016. The areas covered by vegetation had a steady decrease from $106.51 \mathrm{~km}^{2}$ (87.36\%) in 1989 down to $89.56 \mathrm{~km}^{2}(73.46 \%)$ in 2002, and $42.11 \mathrm{~km}^{2}(34.54 \%)$ in 2016. The trend in built-up was 9.59\% in 1989, 24.49\% in 2002, and $62.61 \%$ in 2016, and a projected land use extent was $82.82 \%$ in 2030. The test result of the hypothesis also showed that there is significant spatial variation in the extent of the built-up area in the Yenagoa metropolis between 1989-2016. This study recommended the enforcement of timely and appropriate land use planning which considers the requirements of social, economic, and environmentally sustainable development.
\end{abstract}

Keywords: Geographical Information System (GIS), Dynamics, Urbanization, Land use, Land cover, Remote sensing.

\section{INTRODUCTION}

The expansion in the human populace has brought about expanding paces of ecological changes in the recent decade. This expansion is liable for this change in urban development. The most striking component of the quick urbanization process on the worldwide scale is the expanding agglomeration of the total populace, evaluated at over 6.8 billion live in or around the metropolitan region and individuals are moving into urban communities at a rate unheard of since the mechanical unrest (UNHabitat, 2011). The overarching procedure of globalization accelerate the rate of urbanization particularly in many developing nations, especially Africa where numerous nations are as of now moving towards having 40 to 50 percent of their populace living in urban zones (Mabogunje, 2007).

Urbanization is one of the most transformative human land use forms in history and it is probably going to increment in the year to come. It is equivalent to a close perpetual change of the regular habitat (Guneralp and Seto 2013). As confirmed by Agbola (2006) that urbanization a worldwide marvel and is a procedure of spatial concentration of urban populace that is introduced on some fundamental push and pull factors called urban change powers, which he ordered into three significant procedures. These are; regular increment in the populace (National development rate or the proportion of birth to death rates), rustic urban movement, and city addition into the encompassing provincial zones (a genuine extension). The greater part of the total populace as of now dwells in urban regions. This is figure anticipated expected to increment to $60 \%$ by 2050 . Urbanization enormously affects characteristic natural surroundings and assets, and urban development is liable for significant misfortunes in green space and biodiversity Urban territories can, in any case, offer a wide assortment and mosaic of living spaces and structures, from halfway vegetated downtown areas to different sorts of nurseries in suburbia and neighborhoods, including city parks, graveyards, 
timberland remainders, and decrepit land with ruderal vegetation (Marzluff et al., 2001). They fill in as mind boggling human frameworks that pull in individuals, venture, and course of assets (Singh, 2014). In light of Yeh (2002), these never-ending suburbias have prompted a great deal of basic, natural, and social issues that lead to the loss of important rural land just as vegetal spreads. Wirth (1938) saw an urban focus as a perpetual settlement with enormous populace size, high populace thickness, and social heterogeneity.

Urban dynamics can be described as the changing developments of individuals, object and data in a city that is related with a few issues that normally happen generally in the large urban areas of the world (which is increasingly significant in development nations) for example, urban spread; environmental change and air population; poor urban waste administration, insufficient water flexibly, deficient vitality, general medical issues, falling apart downtown framework, traffic blockage, ecological debasement, pressure on common living spaces, etc. (UNEP, 2004). Urban communities possess just about $3 \%$ of the world's property however expend $75 \%$ of its assets and produce a comparable level of its waste (Firman, 2013). Urban communities are significant supporters of environmental change since they contribute roughly $75 \%$ of the ozone harming substance (GHG) outflows (Singh, 2014). They produce huge ecological impressions, including characteristic living space change, pollution of air and water, and so on.

Most studies in Nigeria center on large sized urban areas across the country like Lagos, Port Harcourt, Ibadan, Kano and Abuja (David and Wong Kim, 2003; Mabogunje, 2007 and Oyeleye, 2013) along these lines overlooking the medium-sized urban areas like Yenagoa. Yenagoa city's development has presented genuine dangers to the little scope ranchers and the common habitat as the encompassing farmlands and close by country networks become some portion of the city's extension zones. Be that as it may, the degree and spatial characteristics of the city's expansion and its impact on other LULC types are not well recorded. Consequently, this study was conducted to evaluate urbanization dynamics in the Yenagoa metropolis through spatial land-use variation between 1989-2016. The specific objectives are to analyze the Landuse/Landcover changes in Yenagoa metropolis; predict the rate of urban growth in Yenagoa metropolis and examine the variation in the spatial extent of the built-up area in the study area between 1989-2016

\section{METHOD AND MATERIAL}

\subsection{Study area}

Yenagoa turned into a state Capital when Bayelsa state was created 1996, Yenagoa is geographically situated between Latitude $4^{0} 47^{\prime} 15^{\text {ee }} \mathrm{N}$ and $5^{0} 11^{\prime} 55^{\prime \prime} \mathrm{N}$ and Long. $6^{0} 07^{\prime} 35^{\prime \prime} \mathrm{E}$ and $6^{0} 24^{\prime} 00^{\prime \prime} \mathrm{E}$ and it lies within 31 and $32^{\prime \prime} \mathrm{N}$ of World Geodetic System 1984 "WGS84" (Ndiwari, 2014). The study area absolute populace is 352,285 which 182,240 are male and 170,045 females in 2006 (National Population Commission, 2010) while the anticipated figure for 2015 is 459,693 (Health Development Plan: Bayelsa State Ministry of Health, 2010). Yenagoa falls under the freshwater swamp timberland vegetation, which contains tall and thick obscure trees. Climbers, bushes, grasses, swamps, streams, rivers, lakes, and so on the vegetation is overwhelmed by the economically Raffia palm, Palm tree, wild or African mango that produces Ogbono. The soil is mainly deltaic as all regions of the Niger Delta have a deltaic soil. Yenagoa has been a moist semi-hot equatorial climate (the AF sort of the Koppen's arrangement of atmosphere)

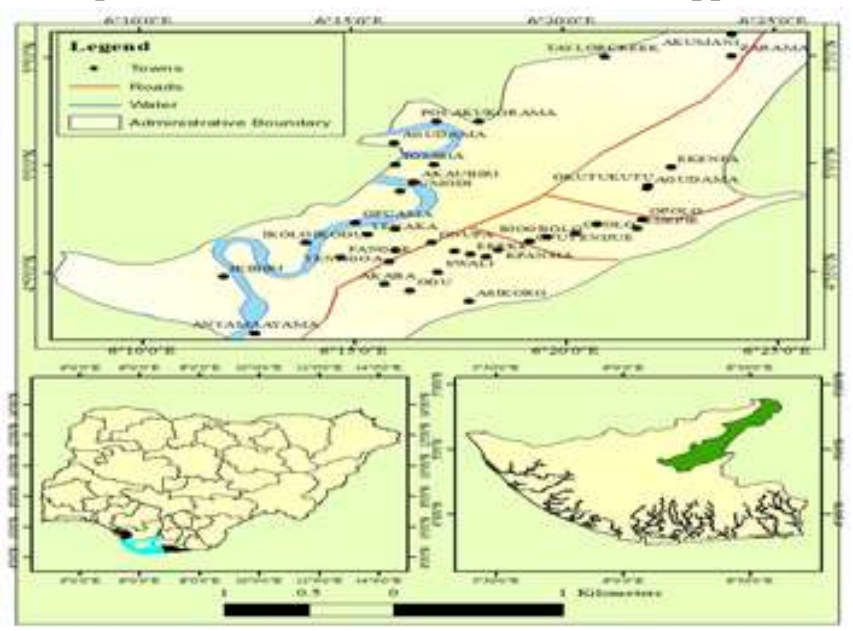

Fig 2.1: Showing the Study Area 


\subsection{Research Design}

The study centers on evaluating the urbanization dynamics in the Yenagoa city since pre-state creation. The investigation utilized principally remote sensing and GIS techniques in acquiring data, analyzing, and presentations. Likewise, descriptive statistics were used to check the percentage changes in the various land-uses.

\subsection{Data and Sources}

Landsat TM (Thematic Mapper) image of 1989, $\mathrm{ETM}^{+}$(Enhanced Thematic Mapper Plus) of 2002, and OLI-TRIS (Operational Land Imager-Thermal Infrared Sensor.) of 2016 of path 189 and row 057 were downloaded from the United States Geological Survey (USGS). For urban land cover classifications with Landsat $\mathrm{ETM}^{+}$, the most useful bands are visible and near-infrared (bands 4, 3 and 2), and bands 5, 4, and 3 in the case of Landsat OLI-TRIS. Other secondary data for this study were sourced from books, journals, internet, etc.

Table 2.1: Satellite Image description.

\begin{tabular}{cccccc}
\hline Date & Sensor & $\begin{array}{c}\text { Spatial } \\
\text { Resolution }\end{array}$ & Landsat series & No of bands & $\begin{array}{c}\text { Radiometric } \\
\text { Resolution }\end{array}$ \\
$4^{\text {th }}$ Mar,.1989 & TM & $30 \mathrm{~m}$ & 5 & 7 & 8 bits \\
$6^{\text {th }}$ Mar. 2002 & ETM $^{+}$ & $30 \mathrm{~m}$ & 7 & 8 & 9 bits \\
$27^{\text {th }}$ Feb. 2016 & OLI-TIRS & $30 \mathrm{~m}$ & 8 & 11 & 16 bits \\
\hline
\end{tabular}

\subsection{Data Processing and Analysis}

\subsubsection{Landuse/Landcover changes in Yenagoa metropolis}

The satellite images $(1989,2002$, and 2016) were imported into Idrisi Selva software for the image processing (Subsetting, composite, classification, and so on.), the images were enhanced for visualization purpose, and afterward the study area was subset out of the full scene The images were classified using supervised classification and A maximum likelihood classifier was utilized in arranging the image. Four classes of land use type were distinguished was used in the classification which was modified from Anderson (1976) classification scheme as shown in table 2.2, and a worth or code given to Vegetation is 1, Bareland 2, Waterbody 3, and Builtup 4. After which it was embellished utilizing Arc Map 10.4

Table 2 .2: Image Classification Scheme

\begin{tabular}{lll}
\hline S/N & $\begin{array}{l}\text { Landuse/ Landcover } \\
1\end{array}$ & $\begin{array}{l}\text { Vegetation } \\
\text { Consists of Vegetation (forest) cover, cultivated land, and grassland. }\end{array}$ \\
2 & Bareland & Consists of marshy bare surface, flood plains, etc. \\
3 & Waterbody & Consists of open water bodies such as streams, lakes, and rivers. \\
4 & Builtup Area & $\begin{array}{l}\text { Consists of concrete and impervious surface, which is mainly; } \\
\text { Commercial, industrial, institutional, and residential buildings. } \\
\text { Large open transportation facilities and local roads. }\end{array}$ \\
\hline
\end{tabular}

\subsubsection{Predicting the rate of urban growth in Yenagoa metropolis}

The Markov Chain analysis was actualized utilizing the Markov module in the Idrisi Selva software. A Markov procedure is one in which the condition of a framework at time two (2) can be predicted by the condition of the framework at time one (1). Change in land use designs between the two realized dates was utilized to build transition probability matrix and a transition area file; these in turn were used to make the prediction. The transition probability is likelihood that land use would remain the same or change in the future (Eastman 2009). In Idrisi Selva, Cellular Automata analysis is practiced by the CA Markov module. The CA Markov module takes as information the land-use map (y) from which changes ought to be projected, the advances zones record delivered by Markov from the analysis of that image (y), and a previous one (x), and an assortment of suitability images 1 that communicates the suitability 
of a pixel for every one of the land use types viable. It then begins an iterative procedure of reallocating the landcover until it meets the area totals predicted by the Markov module. The Markov module ascertains the probability of the raster cells in each land-use class to transition to other land uses.

\subsubsection{Variation in the Spatial Extent of Built-Up Area between 1989-2016.}

Variation in the spatial extent of the Built-up area between 1989 - 2016 was verified by hypothesis

Hypotheses Testing

Ho: There is no significant variation in the spatial extent of the built-up area in the Yenagoa metropolis between 1989 to 2016.

H1: There is significant spatial variation in the extent of the built-up area in the Yenagoa metropolis between 1989 to 2016. The chi $\left(\mathrm{X}^{2}\right)$ statistical techniques were also used to test the hypotheses

Chi-square $\left(\mathrm{X}^{2}\right)$ formula $=\sum(\mathrm{O}-\mathrm{E})^{2} / \mathrm{E}$

Where; $\mathrm{O}=$ Observed Frequency

$\mathrm{E}=$ Expected Frequency

\section{RESULTS AND DISCUSSION}

The results from the classified Landsat images, based on the aim of the study; which is to assess the urbanization dynamics in Yenagoa metropolis since pre-state creation. The results are presented to inform of maps and statistical tables.

\section{1: Land cover change between 1989, 2002, and 2016}

From the classified Landsat images of 1989, 2002, and 2016; four classes of land cover types were identified namely; Vegetation, bareland, Waterbody, and Builtup. In 1989, vegetation had the highest landcover area of $106.506 \mathrm{~km}^{2}$ (87.4\%), built up had $11.697 \mathrm{~km}^{2}(9.6 \%)$, while bareland and waterbody only accounted for about $3.71 \mathrm{~km}^{2}$ (Table 3.1 and Figure 3.1). As of 1989, Yenagoa was just a riverine community under the then old Rivers state and there was no encroachment of natural vegetation cleared for building because of the low population in the area. In 2002, the builtup area had increased to occupy $29.851 \mathrm{~km}^{2}(24.5 \%)$ of the total area as indicated in figure 3.2. Vegetation had decreased from $87.4 \%$ to $73.5 \%$. This may have been as a result of population growth since Yenagoa was made the capital of Bayelsa state in 1996. Thus, the influx of people into the town greatly increased the need to alter the natural environment for the construction of new and bigger settlements. In 2016, it was discovered from the classified images that the built-up area had significantly increased to covering about $76.33 \mathrm{~km}^{2}(62.6 \%)$ of the total land area in the study area (Figure 3.3). Consequently, the area covered by vegetation reduced to about $42.11 \mathrm{~km}^{2}(34.54 \%)$. It was discovered that waterbody remained almost stable through the three sampled years, while the area covered by bareland reduced from $1 \%$ of the total land area to almost $0.2 \%$ in 2002 and 0.97 by 2016

Table 3.1: Land-use/land-cover for years 1989, 2002, and 2016

\begin{tabular}{llrrrrrr}
\hline S/N & Landcover Classes & $\begin{array}{c}\mathbf{1 9 8 9} \\
\text { Area }\left(\mathbf{k m}^{2}\right)\end{array}$ & \multicolumn{1}{c}{$\mathbf{( \% )}$} & $\begin{array}{c}\mathbf{2 0 0 2} \\
\text { Area }\left(\mathbf{k m}^{2}\right)\end{array}$ & $\begin{array}{c}\mathbf{2 0 1 6} \\
\text { (\%) }\end{array}$ & Area $\left(\mathbf{k m}^{2}\right)$ & \multicolumn{1}{l}{$\boldsymbol{( \% )}$} \\
1 & Vegetation & 106.51 & 87.36 & 89.56 & 73.46 & 42.11 & 34.54 \\
2 & Bareland & 1.25 & 1.02 & 0.02 & 0.02 & 0.97 & 0.80 \\
3 & Waterbody & 2.46 & 2.02 & 2.48 & 2.03 & 2.50 & 2.05 \\
4 & Builtup & 11.69 & 9.59 & 29.85 & 24.49 & 76.33 & 62.61 \\
& Total & 121.91 & 100 & 121.91 & 100 & 121.91 & 100 \\
\hline
\end{tabular}

Source: Classified Landsat images 2017 
International Journal of Advances in Scientific Research and Engineering (ijasre), Vol 6 (8), August -2020

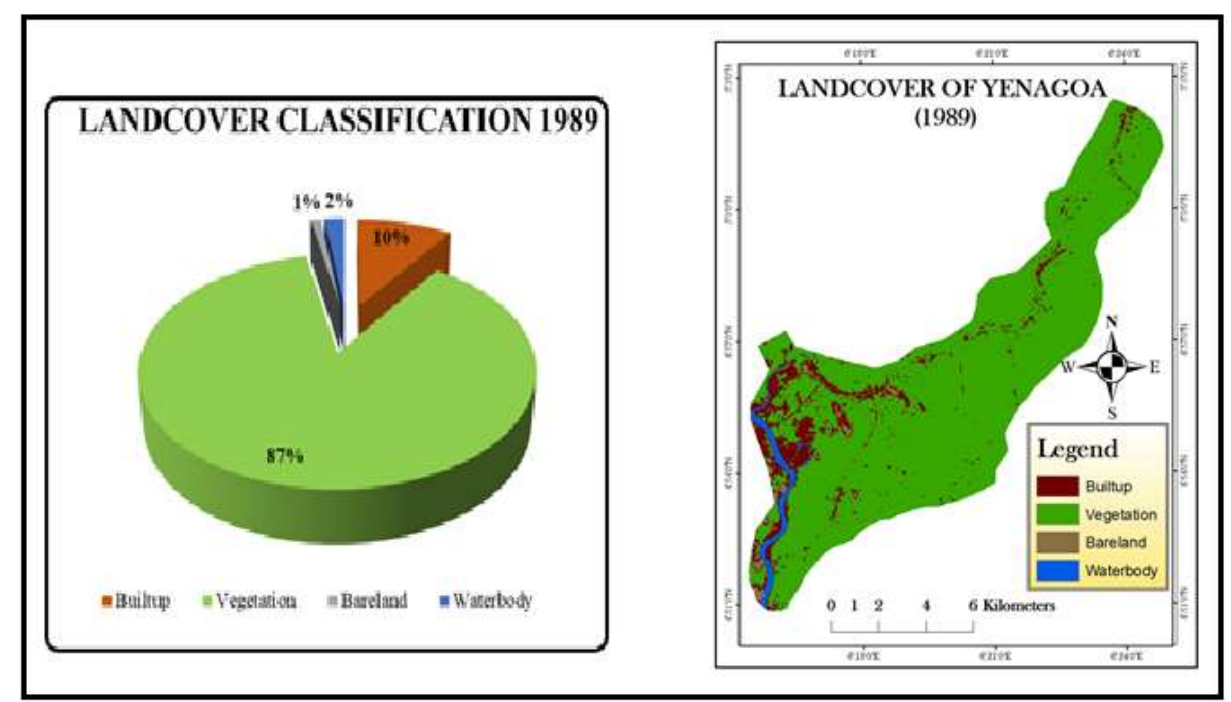

Figure 3.1: Land cover Classification (1989)

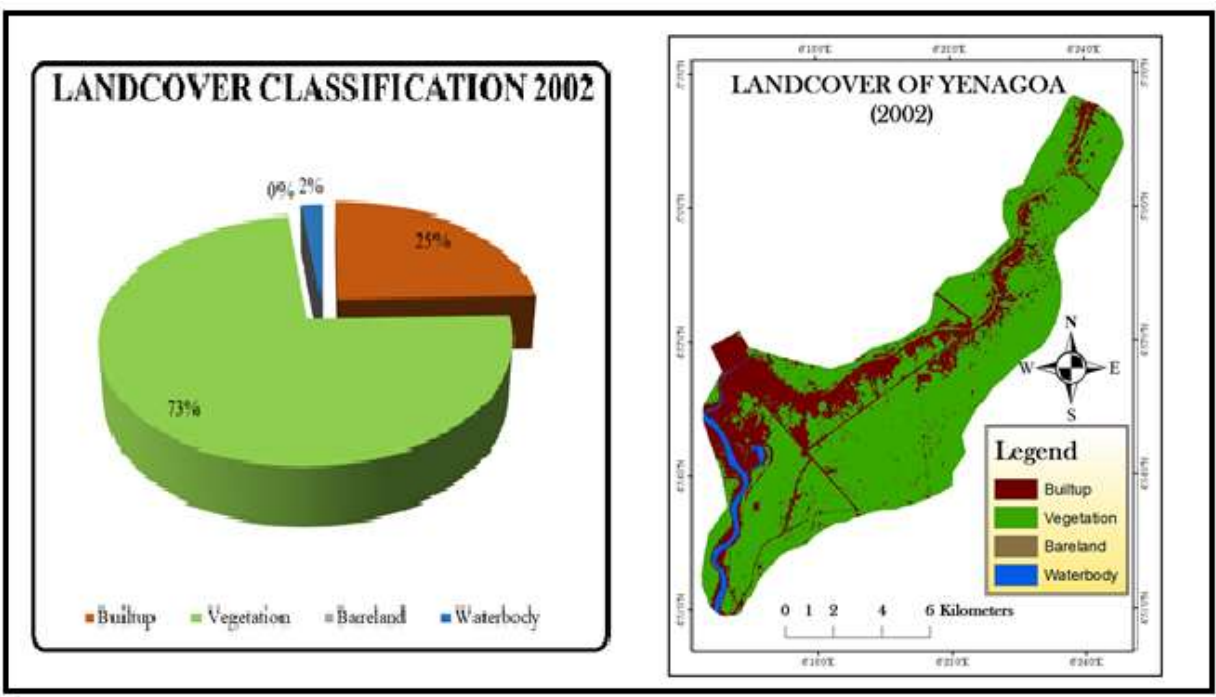

Figure 3.2: Land cover Classification (2002)

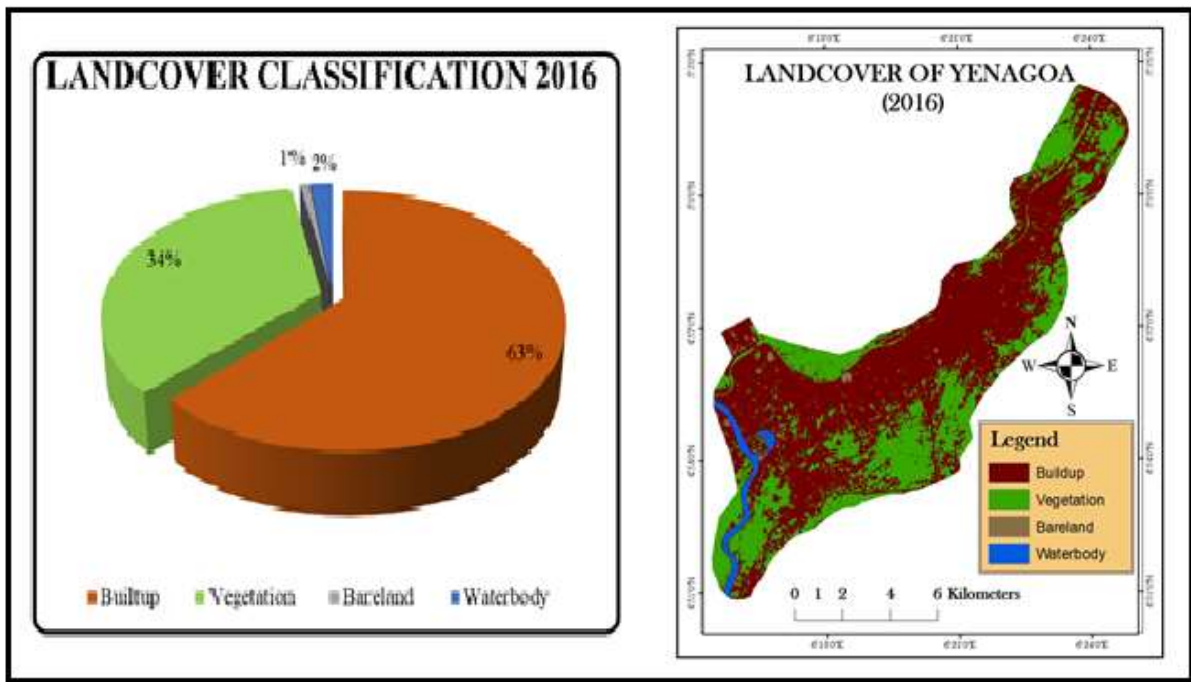

Figure 3.3: Land cover Classification (2016) 


\subsection{Predicted urban growth in Yenagoa metropolis}

Table 3.2 shows a rundown of the rate changes in the spatial extent of various landcover in the Yenagoa city between 1989 to 2016 and a projected landcover extent of 2030. Figure 3.4 shows the projected landcover images of Yenagoa for 2030. The prediction shows a noteworthy decrease in the vegetation region and an expansion in the built-up region. The built-up area which secured a complete area of $76.33 \mathrm{~km} 2(62.61 \%)$ in 2016 is projected to cover 100.97 $\mathrm{km} 2$ in $2030(82.82 \%)$ and this is probably going to have various socio-economic and environmental consequences except if sustainable urban planning and development approaches are instituted. The result demonstrates that there is no single steady pattern in the area coverage of the different land uses over time The significant special case is the built-up area that demonstrated a steady increment after some time, from $11.7 \mathrm{~km} 2(9.59 \%)$ in 1989 to $29.85 \mathrm{~km} 2$ $(24.49 \%)$ and $76.33 \mathrm{~km} 2(62.6114 \%)$ in 2016.

Table 3.2: Land-use/land-cover for years 1989, 2002, 2016 and a projected landuse of 2030

\begin{tabular}{|c|c|c|c|c|c|c|c|c|c|}
\hline \multirow[t]{2}{*}{$\mathrm{S} / \mathrm{N}$} & \multirow{2}{*}{$\begin{array}{l}\text { Landcover } \\
\text { Classes }\end{array}$} & \multicolumn{2}{|l|}{1989} & \multicolumn{2}{|l|}{2002} & \multicolumn{2}{|l|}{2016} & \multicolumn{2}{|c|}{ Projected 2030} \\
\hline & & Area $\left(\mathrm{km}^{2}\right)$ & $(\%)$ & Area $\left(\mathrm{km}^{2}\right)$ & $(\%)$ & Area $\left(\mathrm{km}^{2}\right)$ & $(\%)$ & Area $\left(\mathrm{km}^{2}\right)$ & $(\%)$ \\
\hline \multirow[t]{2}{*}{1} & Vegetation & 106.51 & 87.3 & 89.56 & 73.4 & 42.11 & 34.5 & 17.8 & 14.6 \\
\hline & & & 6 & & 6 & & 4 & & \\
\hline 2 & Bareland & 1.25 & 1.02 & 0.02 & 0.02 & 0.97 & 0.8 & 0.28 & 0.23 \\
\hline 3 & Waterbody & 2.46 & 2.02 & 2.48 & 2.03 & 2.5 & 2.05 & 2.86 & 2.35 \\
\hline \multirow[t]{3}{*}{4} & Builtup & 11.69 & 9.59 & 29.85 & 24.4 & 76.33 & 62.6 & 100.97 & 82.82 \\
\hline & & & & & 9 & & 1 & & \\
\hline & Total & 121.91 & $\begin{array}{l}99.9 \\
9\end{array}$ & 121.91 & 100 & 121.91 & 100 & 121.91 & 100 \\
\hline
\end{tabular}

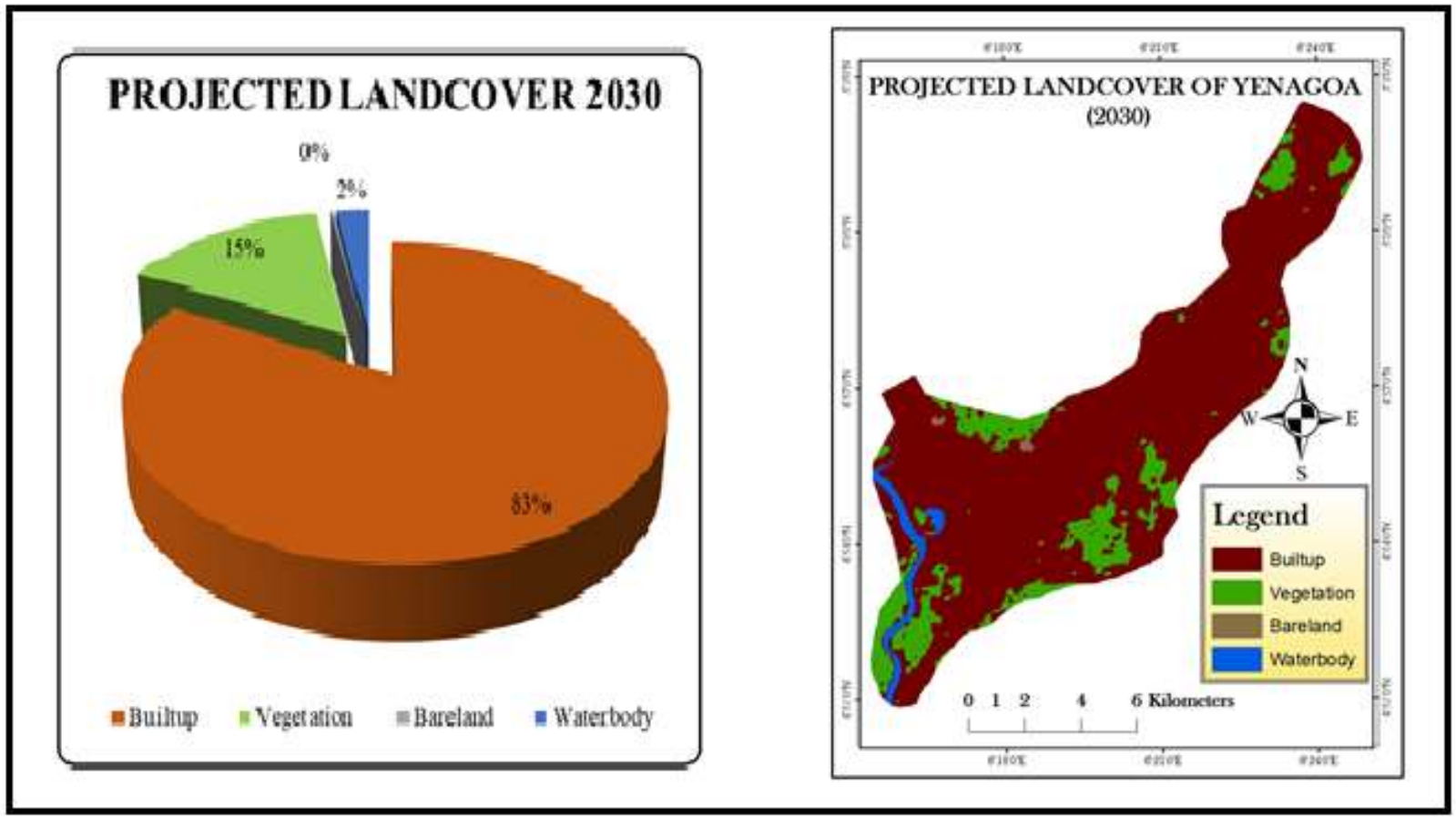

Fig. 3.4: the projected Landcover Dynamics

\subsection{The Variation in the Spatial Extent of Built-Up Area between 1989 to 2016.}

Variation in the spatial extent of Built-up area was verified by hypothesis

Hypotheses Testing

Ho: There is no significant variation in the spatial extent of the built-up area in the Yenagoa metropolis between 1989 to 2016 .

H1: There is significant spatial variation in the extent of built-up area in Yenagoa metropolis between 1989 to 2016 
International Journal of Advances in Scientific Research and Engineering (ijasre), Vol 6 (8), August -2020

Table 5: Chi-square Table for Builtup Area Spatial Dynamics

\begin{tabular}{lllllll}
\hline $\mathbf{S} / \mathbf{N}$ & Builtup Area $($ Year $)$ & $\mathbf{O = O b s e r v e d ~ A r e a ~}\left(\mathbf{k m}^{2}\right)$ & $\mathbf{E}=$ expected frequency & $\mathbf{O - E}$ & $(\mathbf{O}-\mathbf{E})^{2}$ & $(\mathbf{O}-\mathbf{E})^{2} / \mathbf{E}$ \\
1 & 1989 & 11.7 & 39.29 & -27.59 & 761.21 & 19.37 \\
2 & 2002 & 29.85 & 39.29 & -9.44 & 89.11 & 2.27 \\
3 & 2016 & 76.33 & 39.29 & 37.04 & 1371.96 & 34.92 \\
& Total & 117.88 & 117.87 & & & 56.56 \\
\hline
\end{tabular}

Chi square $\left(\mathrm{X}^{2}\right)$ formula $=\sum(\mathrm{O}-\mathrm{E})^{2} / \mathrm{E}=56.56(\mathrm{p})$

Degree of Freedom (Df) $=$ n-1

$3-1=2$

The critical value of $X^{2}$ from the Chi-square table at 2 degrees of freedom and 0.05 confidence level, $\alpha=5.991$, (see Appendix 1). Consequently, since the calculated value $\mathrm{P}$ (56.56) is greater than the critical value $\alpha$ (5.99), we reject the null hypothesis and accept the alternative hypothesis; which states that; there is significant spatial variation in the extent of built-up area in Yenagoa metropolis between 1989 to 2016. The result demonstrates that there has been impressive variation in the different urban land use tested in the studied area over the inspected period

\subsection{Discussion}

The rate of vegetation degradation in the study area is getting disturbing due to the ever-expanding part of the urban condition, for example, building, streets, and other financial framework. The study area has experienced different urban landcover changes; it is shown that the spatial extent of the built-up area indicated a reliable increment over time. The study reveals that between 2002-2016 periods, Yenagoa has seen substantially more urban development than the preceding period. This demonstrates an exceptional increment in the urban developed regions and this quick pace of urban extension has been found to have infringed enormously into other urban landcover as appeared in the classified Landsat image of 1989, 2002, and 2016 and anthropogenic of 2030. For example, as the populace developed in Yenagoa, vegetation started to diminish to help the expanding requirement for land to help private, business, and institutional turn of events. The four classes were captured for each studied year yet more accentuation on the built-up land because the built-up land is comprised of anthropogenic exercises and for sure it is a significant one that influences different classes. The trend in the spatial development of Yenagoa has a combined direct example that happened along the significant stream courses e.g., the renowned Swali people group alongside the River Nun.

Fabiyi (2002) and Eludoyin (2011) concurred with certainty that urbanization has been the main impetus toward the rate at which a specific land-use and landcover changes over time. The movement of individuals into the city had taken the vegetal covers to build houses, industries, and roads. Lambin and Geist (2006) perceived that increasing in humans.is the prevailing power in global environmental change. In 1989, vegetation-covered the largest portion $(87.36 \%)$ of the total area while the built-up area was just $(9.59 \%)$ of the total area. As confirmed by Alagoa (2009) spin-off of the formation of Bayelsa State, Yenagoa was only a direct network along the Epie spring under old Rivers state, with moderately barely any private and business structures. In any case, when Yenagoa turned into the capital city, the state government set out upon a fast development to encourage managerial exercises which prompted the quick urbanization of the territory and inevitably brought about the adjustment of its regular vegetation. In 2002, the built-up area had expanded to occupy $29.851 \mathrm{~km} 2(24.5 \%)$ of the of the total area, and vegetation had diminished from $87.4 \%$ to $73.5 \%$ and this was further increased significantly to $62.61 \%$ of the total area in 2016. It is predicted to be even hazardous later because the landcover projected revealed that the built-up area has a great chance of occupying about $82,82 \%$ of the total area without satisfactory checks and the board plans 


\section{CONCLUSION AND RECOMMENDATION}

This study was designed to assess the urbanization dynamics in Yenagoa. To achieve this aim, the study focused on analyzing the Landuse/Landcover changes in Yenagoa between 1989-2016; predicting the rate of urban growth in Yenagoa metropolis and examine the variation in the spatial extent of built-up area in the study area between 19892016 which was generated by classified Landsat satellite images of 1989, 2002, and 2016 into four predefined classes (built-up, vegetation, bare land, and waterbody). Several findings were achieved as a result of the various analyses and the finding has discussed adequately in the proceeding chapter. It was evident from the classified image that there has been a significant land-use and landcover change in the area; where the spatial extent of vegetation cover had a steady decreased from $215 \mathrm{~km}^{2}(81 \%)$ in 1989 down to $184.3 \mathrm{~km}^{2}(70 \%)$ in 2002 , and $166.3 \mathrm{~km}^{2}(63 \%)$ in 2016 . however, the major exception is the built-up area that showed a consistent increase in spatial extent over time, from $7.5 \mathrm{~km}^{2}(2.9 \%$ of the total area) in 1989 to $13.8 \mathrm{~km}^{2}(5.2 \%)$ and $36.93 \mathrm{~km}^{2}(14 \%)$ in 2016 . The changes could be attributed to the growth of urban areas due to the creation of Bayelsa state in 1996 and the establishment of Yenagoa as the capital city, which also led to the increase in population through natural (increased birth rate and reduced death rate) and immigration.

Finally, the study also revealed (from the review of other literature) that haphazard development, caused by urbanization and demographic factors, is one of the major factors contributing to the land-use dynamics in the study area. The test result of the hypothesis which states that; there is no significant spatial variation in the extent of the built-up area in the Yenagoa metropolis between 1989 to 2016. The result also reveals that there is significant spatial variation in the extent of the built-up area in the Yenagoa metropolis between 1989-2016. And this can be attributed to the modernization process which is evident in the Burgess concentric zone model; where urban centers begin in a relatively small area within the heart of the town (core) at the beginning of the development process. This study recommended the following approach in solving and planning for the rapid urbanization within the study area

- Enforcement of timely and appropriate land use planning which considers the requirements of social, economic, and environmentally sustainable development.

- Urban renewal can be done to restructure, re-plan, and rehabilitate the blighted parts of our urban areas.

- There is a need for effective implementation of policies and strategies, the extent and rate of urban land use dynamics and its multitude impacts should be well understood by all stakeholders including planners, policymakers, environmentalists, and people in general.

\section{REFERENCES}

1. UN Habitat. (2011). Cities and climate change: global report on human settlements. Earth scan, London

2. Mabogunje A. L. (2007) Developing Mega Cities in Developing Countries, is the text of a lecture delivered at a Colloquim organized by the 2007 Graduating Class, Department of Geography, the University of Lagos on Wednesday, 12 September 2007

3. Guneralp, B., and Seto, K.C. (2013) Future of global expansion uncertainties and implication for biodiversity conservation. Environ. Res. Lett., 8, 014025

4. Agbola T (2006). Sustainable Urbanization and the New Urban Planning: Dilemma of New Opportunities and the Challenges for Nigeria Technocratic Planners. A paper presented at the $2^{\text {nd }}$ Postgraduate Diploma Regular Forum lecture series. In the Dept. of Urban and Regional Planning, Rufus Giwa Polytechnic, Owo, $3^{\text {rd }}$ June 2006

5. Marzluff JM, Bowman R, Donnelly R (eds) (2001) Avian ecology and conservation in an urbanizing world. Kluwer, Boston

6. Singh, R.B. (ed.), (2014); Urban Development Challenges, Risk and Resilience in Asian Mega Cities. Tokyo: Springer.

7. Ginsburg, N., Koppel, B., McGee, T. G. (eds) (1991) The extended metropolis: settlement transition in Asia. University of Hawaii Press, Honolulu 
International Journal of Advances in Scientific Research and Engineering (ijasre), Vol 6 (8), August -2020

8. Yeh, A. G. O. (2002). Urban form and density in sustainable development. Centre of Urban Planning and Environmental Management, the University of Hong

9. Wirth, L. (1938). Urbanism as a way of life. American Journal of Sociology 44: 1-24.

10. Firman, T. (2013). Demographic patterns of Indonesia's urbanization, 2000-2010: Continuity and change at the macro level. XXVII IUSSP International Population Conference. Korea, 26-31 August 2013Ginsburg, N., Koppel, B., McGee, T. G. (Eds) (1991) the extended metropolis: settlement transition in Asia. University of Hawaii Press, Honolulu

11. David S. Bell and Bun Woong Kim (2003), Managed Urban Development or Uncontrolled Urban sprawl. The case of Seoul South Korea, Chowong press, Seoul - South Korea

12. Oyeleye I. (2013) Challenges of Urbanization and Urban Growth in Nigeria. American Journal of Sustainable Cities and Society Issue 2, Vol.1.

13. Fabiyi O (2002). Geographical information system, techniques and method|" research support services, Ibadan, Nigeria pp.1-147

14. Eludoyin, O.S, wokocha C.C, and Ayolagha G. (2011) GIS Assessment of Landuse and Landcover Changes in Obio/Akpor L.G.A. Rivers state, Nigeria" Research Journal of Environmental and Earth Science, Vol. 3 No. 4, pp. 307-313.

15. Lambin, E.F., Geist, H.J., and Rindfuss, R.R. (2006) "Introduction: local processes with global impacts ", In Lambin, E.F., Geist, H.J(Eds), Land-use and Land-Cover Local Processes and Global impacts. The IGBP Series. Springer-Verlag, Berlin, Heidelberg, pp. 1-8

16. Alagoa E.J. (2009) “The Wilberforce Island Centre for Niger Delta Studies" Niger Delta University Wilberforce Island, Amassoma, Bayelsa State

*Corresponding Author: bukkylam2003@yahoo.com

\section{Appendix}

Appendix 1: Chi-square $\left(\mathrm{X}^{2}\right)$ table

\begin{tabular}{lcccccccccccc}
\hline & \multicolumn{10}{c}{ Probability } \\
$\begin{array}{l}\text { Degree of } \\
\text { Freedom }\end{array}$ & 0.95 & 0.90 & 0.80 & 0.70 & 0.50 & 0.30 & 0.20 & 0.10 & 0.05 & 0.01 & 0.00 \\
1 & & & & & & & & & & & \\
2 & 0.00 & 0.02 & 0.06 & 0.15 & 0.46 & 1.07 & 1.64 & 2.71 & 3.84 & 6.64 & 10.83 \\
3 & 0.10 & 0.21 & 0.45 & 0.71 & 1.39 & 2.41 & 3.22 & 4.60 & 5.99 & 9.92 & 13.82 \\
4 & 0.35 & 0.58 & 1.01 & 1.42 & 2.37 & 3.66 & 4.64 & 6.25 & 7.82 & 11.34 & 16.27 \\
5 & 0.71 & 1.06 & 1.65 & 2.20 & 3.36 & 4.88 & 5.99 & 7.78 & 9.49 & 13.28 & 18.47 \\
6 & 1.14 & 1.61 & 2.34 & 3.00 & 4.35 & 6.06 & 7.29 & 9.24 & 11.07 & 15.09 & 20.52 \\
7 & 1.63 & 2.20 & 3.07 & 3.83 & 5.35 & 7.23 & 8.56 & 10.64 & 12.58 & 16.81 & 22.46 \\
8 & 2.17 & 2.83 & 3.82 & 4.67 & 6.35 & 8.38 & 9.80 & 12.02 & 14.07 & 18.48 & 24.32 \\
9 & 2.73 & 3.49 & 4.49 & 5.53 & 7.34 & 9.52 & 11.03 & 13.36 & 15.51 & 20.09 & 26.12 \\
10 & 3.32 & 4.17 & 5.38 & 6.39 & 8.34 & 10.66 & 12.24 & 14.68 & 16.92 & 21.67 & 27.88 \\
& 3.94 & 4.86 & 6.18 & 7.27 & 9.34 & 11.78 & 13.44 & 15.99 & 18.31 & 23.21 & 29.59 \\
& & & & No significant & & & & & Significant & \\
\hline
\end{tabular}

